\title{
Information, ICTs and Small Enterprise: Findings from Botswana
}

Link to publication record in Manchester Research Explorer

\section{Citation for published version (APA):}

Duncombe, R., \& Heeks, R. (1999). Information, ICTs and Small Enterprise: Findings from Botswana.

(Development Informatics Working Paper Series; No. 7).

http://unpan1.un.org/intradoc/groups/public/documents/nispacee/unpan015541.pdf

\section{Citing this paper}

Please note that where the full-text provided on Manchester Research Explorer is the Author Accepted Manuscript or Proof version this may differ from the final Published version. If citing, it is advised that you check and use the publisher's definitive version.

\section{General rights}

Copyright and moral rights for the publications made accessible in the Research Explorer are retained by the authors and/or other copyright owners and it is a condition of accessing publications that users recognise and abide by the legal requirements associated with these rights.

\section{Takedown policy}

If you believe that this document breaches copyright please refer to the University of Manchester's Takedown Procedures [http://man.ac.uk/04Y6Bo] or contact uml.scholarlycommunications@manchester.ac.uk providing relevant details, so we can investigate your claim.

\section{OPEN ACCESS}




\section{Development Informatics}

\section{Working Paper Series}

The Development Informatics working paper series discusses the broad issues surrounding information, information systems, and information technology in the process of socio-economic development

Paper No. 7

\section{Information, ICTs and Small Enterprise: Findings from Botswana}

\section{RICHARD DUNCOMBE \& RICHARD HEEKS}

November 1999

Published Institute for Development Policy and Management

by: $\quad$ University of Manchester, Precinct Centre, Manchester, M13 9GH, UK Tel: +44-161-275-2800/2804 Fax: +44-161-273-8829

Email: idpm@man.ac.uk

Web: http://www.man.ac.uk/idpm

View/Download from: http://www.man.ac.uk/idpm/idpm_dp.htm\#devinf_wp

Educators' Guide from: http://www.man.ac.uk/idpm/educdi.htm 


\section{Table of Contents}

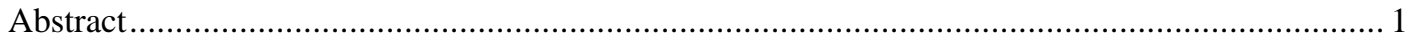

A. Researching Information, ICTs and Small Enterprise...................................................2

B. The Botswana Research Project...................................................................................3

C. Research Findings ................................................................................................5

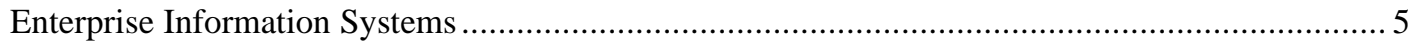

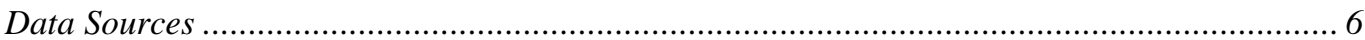

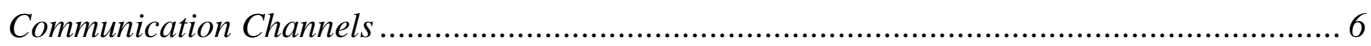

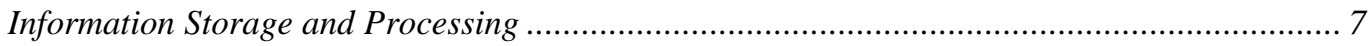

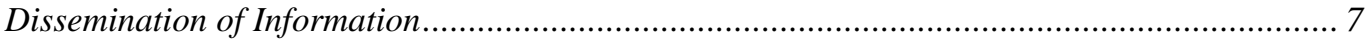

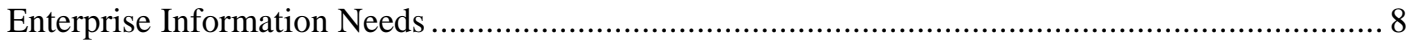

Critical Problem Areas .................................................................................................. 8

Enterprise Information Gaps...................................................................................... 8

D. Conclusions................................................................................................................................9

Recommendations for Enterprise Categories ........................................................... 11

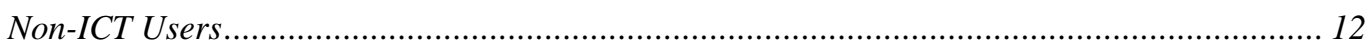

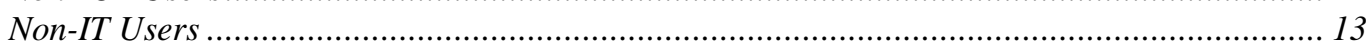

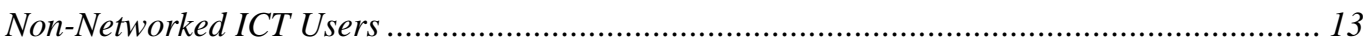

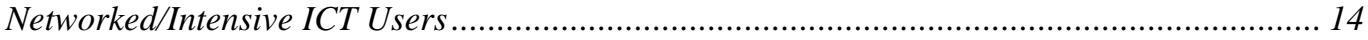

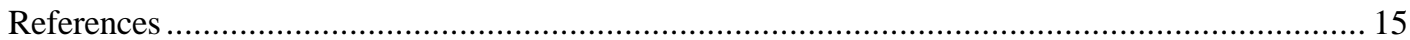




\title{
Information, ICTs and Small Enterprise: Findings from Botswana
}

\author{
Richard Duncombe \& Richard Heeks ${ }^{1}$ \\ IDPM, University of Manchester, UK \\ (Contact: richard.heeks@man.ac.uk) \\ 1999
}

\begin{abstract}
The potential contribution of information and communication technologies (ICTs) to small enterprise development can only be assessed by first understanding current information practices and needs in such enterprises. This paper reports findings from a questionnaire and interview survey of formal sector enterprises in Botswana based on this approach.

The survey first mapped current enterprise information systems, finding there was a strong reliance on informal systems. It also mapped current information needs. Such needs must be kept in perspective since they may be less important than (though intertwined with) needs for other resources such as finance, skills and new markets. Where information systems are improved, changes to informal, non-electronic systems must be considered alongside changes to formal, ICT-based systems.

Interventions, whether by entrepreneurs or support agencies, must also be differentiated. The paper therefore concludes by offering an information-related categorisation of enterprise types with different information systems and different intervention requirements.
\end{abstract}

\footnotetext{
${ }^{1}$ An amended version of this paper has been submitted to Small Enterprise Development. The work reported here was supported by a research grant from the UK Department for International Development.
} 


\section{A. Researching Information, ICTs and Small Enterprise}

Much is being made of the potential for information and communication technologies (ICTs) to assist small enterprise development (Mansell and Wehn, 1998; World Bank, 1998). This potential has spawned a good deal of comment, much of it based on speculation rather than research. A few research studies are now being undertaken and reported (e.g. Barton and Bear, 1999; Ferrand and Havers, 1999; Kole, 1998). However, many - if not most - such studies have taken a techno-centric approach. That is to say, they have made technology the starting point and the main focus. Such studies typically take a predetermined view that new technology is the solution to development problems; that it should be as liberally applied as possible; and that initiative failures are due to technical issues or to the inability of the humans involved to appreciate and champion the wonders of ICTs.

The research project reported here also sought to understand the potential for application of information and communication technologies to small enterprise development. However, it took a broader, more critical and more systemic approach that had three main components (summarised in Figure 1):

1. Information is the key to understanding ICTs. Information and communication technologies may be defined as 'electronic means of capturing, processing, storing, and disseminating information'. All these technologies do is provide new mechanisms for handling an existing resource: information. We can therefore understand nothing about ICTs unless we first understand information practices and needs. This research therefore began not with the technology as its starting point but with the existing information and communication practices of small enterprises, with the role of those practices within the enterprise's main business systems, and with enterprise requirements for improvements in those practices.

2. ICTs are not the only 'technology' that handles information. ICTs are based on digital information held as $1 \mathrm{~s}$ and $0 \mathrm{~s}$, and comprise computer hardware, software and networks. Other information-handling technologies include (Heeks, 1999):

- 'Intermediate' technology, still based largely on analogue information held as electro-magnetic waves such as radio, television and telephone.

- 'Literate' technology, based on information held as the written word such as books and newspapers.

- 'Organic' technology, based solely on the human body such as the brain and sound waves.

Any study of information and small enterprise must therefore encompass these other technologies since there may be situations in which they are more appropriate than ICTs.

3. Information systems are more than just technology and information. In building up a systemic model of ICTs, two separate elements have already been identified: the technology itself and the information on which it operates. In order to make this useful, we add in two further components: processes of purposeful activity and people to undertake those processes. All of these together now make up an 'information 
system', such as a support system that helps staff in an enterprise share information with suppliers using electronic mail. But this information system cannot sit in a vacuum. It exists within an environment of institutions (organisations, groups, markets) and of influencing factors (political, economic, socio-cultural, technical and legal). Recommendations, in particular, need to understand this environment and the constraints it might impose.

Figure 1: A Systemic View of Information and Communication Technologies

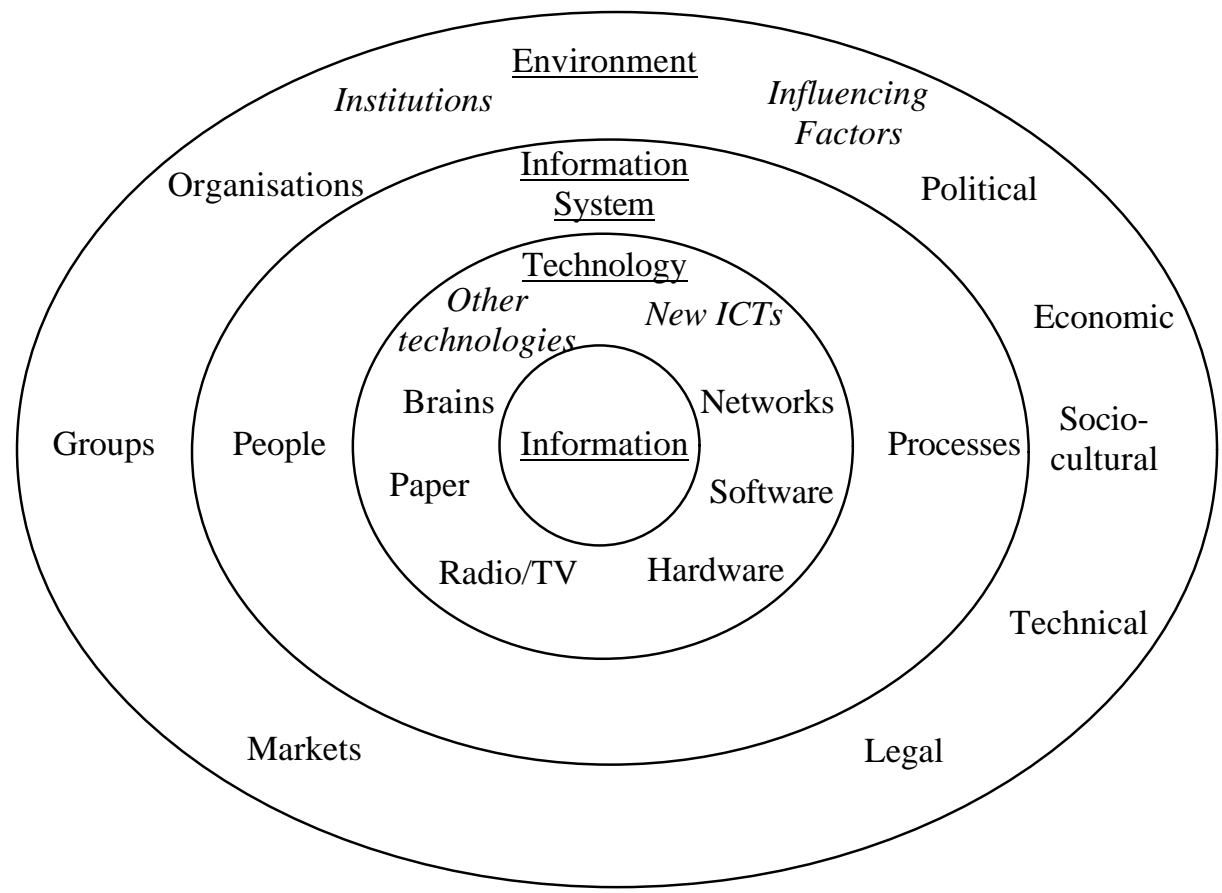

\section{B. The Botswana Research Project}

Botswana was chosen as the site for fieldwork for three main reasons. First, there are a large number of small enterprises of many different types in many different sectors that are relatively easily accessible ${ }^{2}$. This provided a broad spectrum from which to sample. Second, Botswana's ICT infrastructure is relatively well-developed and usage levels are higher than in many developing countries ${ }^{3}$. It was therefore possible to cover a very broad range of use, from enterprises without access to even a telephone up to those making intensive use of Internet-enabled applications. Findings could also move beyond the "intermittent electricity; bad phone lines; lack of spares" issues that appear repetitively in many reports on ICTs and development.

Third, there is a favourable policy environment. There has been a high level of interest in small, medium and micro-enterprise (SMME) development in Botswana since the

\footnotetext{
${ }^{2}$ In total, there are estimated to be around 50,000 microenterprises (informal sector, 1 or 2 paid employees, family run); 6,000 small enterprises (registered, employing less than 25 employees); and 300 medium enterprises (registered, 25-100 employees) in Botswana (SMME Task Force, 1998). Some $70 \%$ of microenterprises are rural-based; some $80 \%$ of small and medium enterprises are urbanbased. $60 \%$ of registered enterprises are in the retail sector; mainly small food retail outlets and general stores. However, there are also significant numbers in manufacturing, construction, tourism, transportation, finance and business services.

${ }^{3}$ Countrywide, Botswana has a tele-density of 4.83 main lines per 100 inhabitants, compared to a low-income country average of 2.48. It has 33.42 Internet users per 10,000 inhabitants, compared to a low-income country average of 0.89 (ITU, 1998).
} 
approval of a new SMME policy in December 1998 (Ministry of Commerce and Industry, 1999). The policy's prime aim is to encourage further expansion of the SMME sector. In addition, Botswana's Vision 2016 document (Presidential Task Group, 1997) makes a strong commitment to the development of competitive enterprises through use of modern technology, including the implementation of ICTs across all manufacturing and service sectors.

The initial research reported here was targeted at formal sector enterprises, drawn from those recorded in the Botswana Registry of Establishments (CSO, 1997) ${ }^{4}$. Two data collection techniques were focused on enterprise information practices and needs:

- Semi-structured interviews, carried out with an initial sample of 20 enterprises.

- A questionnaire sent to 480 small, medium and micro-enterprises covering nonexporting manufacturers, exporting manufacturers and service-based enterprises ${ }^{5}$.

61 usable questionnaires had been returned at the time of writing (a 13\% response rate). The response profile is summarised in Table 1.

Table 1: Questionnaire Respondent Profile

\begin{tabular}{|c|c|c|c|c|}
\hline $\begin{array}{l}\text { Entrepreneur } \\
\text { Sex }\end{array}$ & $\begin{array}{l}\text { Male } \\
(77 \%)\end{array}$ & $\begin{array}{l}\text { Female } \\
(23 \%)\end{array}$ & & \\
\hline $\begin{array}{l}\text { Entrepreneur } \\
\text { Age }\end{array}$ & $\begin{array}{l}<31 \text { years } \\
(8 \%)\end{array}$ & $\begin{array}{l}31-40 \text { years } \\
(30 \%)\end{array}$ & $\begin{array}{l}>41 \text { years } \\
(62 \%)\end{array}$ & \\
\hline $\begin{array}{l}\text { Entrepreneur } \\
\text { Education }\end{array}$ & $\begin{array}{l}\text { Primary } \\
\text { schooling } \\
(12 \%)\end{array}$ & $\begin{array}{l}\text { Secondary } \\
\text { schooling/above } \\
(88 \%)\end{array}$ & & \\
\hline $\begin{array}{l}\text { Enterprise } \\
\text { Size }\end{array}$ & $\begin{array}{l}<5 \text { employees } \\
(26 \%)\end{array}$ & $\begin{array}{l}5-29 \text { employees } \\
(50 \%)\end{array}$ & $\begin{array}{l}\text { 30-99 employees } \\
(24 \%)\end{array}$ & \\
\hline $\begin{array}{l}\text { Enterprise } \\
\text { Ownership }\end{array}$ & $\begin{array}{l}\text { Botswana } \\
\text { citizen-owned } \\
(57 \%)\end{array}$ & $\begin{array}{l}\text { Foreign citizen- } \\
\text { owned } \\
(30 \%)\end{array}$ & $\begin{array}{l}\text { Joint ownership } \\
(10 \%)\end{array}$ & $\begin{array}{l}\text { Foreign } \\
\text { subsidiary } \\
(3 \%)\end{array}$ \\
\hline
\end{tabular}

The profile components of sex, age and ownership are in line with previous formal sector profiles (BOCCIM, 1994; Briscoe, 1995). However, as was to be expected from a postal questionnaire, there were some skews. In particular there was a higher proportion of educated entrepreneurs and of larger enterprises that in the main population. There is also likely to have been a skew towards ICT users. Figures given below on technology use may therefore be somewhat greater than those for the whole population of formal sector enterprises.

\footnotetext{
${ }^{4}$ A secondary phase of fieldwork is currently underway involving more in-depth observation within enterprises, more interviews in non-formal sector enterprises, and more in-depth assessment of the role of intermediary organisations.

${ }^{5}$ The sample was drawn equally from manufacturing and services. The four manufacturing sub-sectors covered were: textiles,

clothing and leather products; wood products, furniture and crafts; building and construction materials; and printing and publishing. The four services sub-sectors covered were: tourism; IT and computing; transport; and engineering and technical services.
} 


\section{Research Findings}

\section{Enterprise Information Systems}

Figure 2 presents the model of enterprise information systems used as the basis for investigation.

Figure 2: Enterprise Information System Model

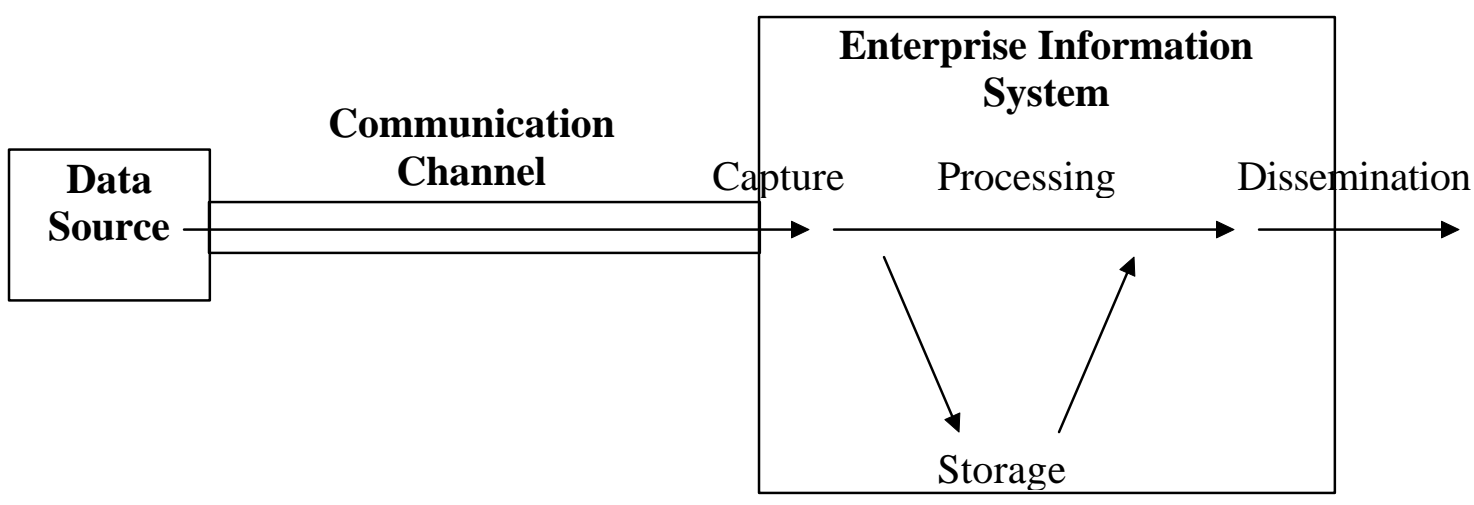

Before exploring the findings about these information system components in more detail, though, the balance between informal and formal information practices must be highlighted. The evidence of both questionnaires and interviews shows that current information practices within the survey group are overwhelmingly informal in nature. This was true not only in 'traditional' sectors such as manufacture of clothing, leather and wood products, and construction materials, but also in 'non-traditional' sectors such as tourism, engineering, and IT services.

Sources and channels of informal information were characterised by:

- A high degree of reliance on information obtained through the knowledge and experience of the business owner.

- Information received through informal local networking within the business community.

- Information received through contacts with family and friends.

- Information accumulated through enterprise-specific learning.

Evidence from interviews shows that the exchange of informal information is common across all areas of business activity. For example, information about loans often comes from family and friends (as do the loans themselves); on-the-job training allows information to pass directly from experienced to less experienced employees; business associates will provide information in the form of informal advice or technical assistance; and market information leading to a new contract may frequently be received through the business grapevine or from a family member.

Determining the comparative quality of formally- and informally-provided information is not easy. On the one hand, informal information can be constrained and insular if the entrepreneur's social network is small, closed and knowledge-poor (Barton, 1997). Informal information systems may be particularly deficient for marginalised or 
displaced entrepreneurs who lack a coherent social network. For them, formal (potentially ICT-based) systems may hold more promise.

However, information received through informal sources and channels was rated more highly by most business owners than information from formal institutional sources. This tends to be because entrepreneurs value the time, cost and convenience benefits of informal information systems. For example, information relating to the implications of a new law or regulation is more likely to be accessed from a business associate than a government institution, because the former is quicker and easier. Entrepreneurs also trust informal information sources and find them easy to process.

The exception was enterprises exhibiting a high degree of dependency on government contracting tended to be locked into more formalised information practices. Many of these enterprises seemed to lack access to the informal business networks that are valued by the wider business community, and their entrepreneurs placed a far greater emphasis on information received from external governmental and non-governmental support organisations.

\section{Data Sources}

The results suggest that entrepreneurs depend predominantly on their own 'internally generated knowledge and experience', which has been built up within their present business or as a result of previous employment/business ownership. As just noted, 'externally generated information' is sourced primarily through informal business networks of customers and suppliers or family and friends. In contrast, formal institutional data sources, such as banks, consultants and business support agencies are not seen as particularly important. The exception, also noted above, are non-exporting manufacturers, many of whom are relatively dependent on such institutions. Half of them felt business support institutions were their single most important source of external business information. Other entrepreneur groups found information from formal institutions was not targeted at them, and they were generally less dependent on - and less inclined to deal with - such institutions.

\section{Communication Channels}

The vast majority of respondents in all categories regarded direct contact with customers through face-to-face meetings as the single most effective method of business communication. About $70 \%$ of respondents also frequently used fixed line telephone and fax for their business dealings. Around one quarter of enterprises were using mobile telephony and email, though far more service than manufacturing enterprises; and far more exporters than non-exporters.

Telephone services (including fax) represent the most popular initial investment for businesses. The rapid growth of mobile communications in the past two years is also proof of the value entrepreneurs place on real-time voice communication. The evidence shows that even very small businesses find telephone services advantageous. For example, one rural artisan producing leather goods used telephone-based communications to contact market traders in distant towns and materials suppliers in an adjoining country. The extension of telecommunication services, providing for direct voice (and fax) communication, has been of particular value to SMMEs operating in Botswana, given its large land mass and dispersed population. 
As yet, the appeal of email and Internet-mediated communication remains largely confined to certain specific sectors. The vast majority of formal sector SMMEs serve local markets and rely primarily on locally-generated information. Internet use remains in its infancy and, until the amount of local content is expanded in terms of both volume and quality, it is unlikely that the benefits of information access through networked services will justify the costs for most formal sector SMMEs.

Investments for Internet access are significant in terms of initial financial outlay, running costs, and investments of time and skills. Because of this, such investments would need to be accompanied by significant benefits in terms of regularity of use and quality of information provided. The evidence shows that it is only in specific sectors, such as technical services, the IT sector and travel and tourism, that information access benefits can be achieved as yet. These are all sectors that require regular access to information and/or software across borders, both regionally and world-wide.

By contrast, the benefits of access to telephony services seem likely to far outweigh the comparatively low investment and training costs for a far wider spectrum of enterprises.

\section{Information Storage and Processing}

The majority of entrepreneurs still stored information on paper/cards or in their head, and processed it manually. Use of computers in information storage and processing was highly uneven. Taken overall, the initial fieldwork results suggested significantly higher levels of computer use amongst service-based enterprises than either manufacturing exporters or non-exporting manufacturers. Amongst service-based businesses and manufacturing exporters, information relating to company accounts, for example, was held on computer by nearly $70 \%$ of enterprises surveyed. Amongst nonexporting manufacturers only $9 \%$ had computer-based accounts.

\section{Dissemination of Information}

The primary formal objective of all enterprises is to sustain/increase their sales by means of retaining existing customers and/or locating new customers. There is evidence from the survey that, when promoting their products and services, entrepreneurs have a strong preference for personal contact with customers. $90 \%$ of all business owners regarded face-to-face contact as being very effective for promotion.

Other forms of communication were not considered so effective. This was particularly the case amongst service-based enterprises. Formal methods of media-based marketing are generally not used in Botswana by the small enterprise sector at present. The postal and telecommunications infrastructure is thought to be insufficiently developed and not reliable enough for effective direct telephone sales or the use of direct mail marketing techniques. Marketing and advertising services in Botswana are at an early stage of development and cater predominantly for the corporate sector. Quite apart from these environmental constraints, such services would generally not be affordable by SMMEs. 
Approximately $50 \%$ of those who responded to the survey had Internet access, $43 \%$ used the Internet very often, and 30\% rated it 'very important' as a source of business information. However, there was far less use of the Internet as a means of disseminating information about enterprise products and services. Only $13 \%$ of Internet users regarded it as very effective as a product/service promotion tool, and a further $47 \%$ had not yet used the Internet for business promotion.

In serving domestic markets, Internet-based marketing is not likely to offer any substantial benefits in comparison with other forms of media, which are already underutilised at present. There are, though, likely to be considerable benefits for enterprises whose customers are located outside Botswana. For manufacturing exporters and the tourist industry, a strong Internet presence may become a powerful marketing tool, both for raising the profile of the business and for rapid dissemination of information to potential and existing customers.

\section{Enterprise Information Needs}

\section{Critical Problem Areas}

Information is not the be-all and end-all of enterprise development, and study of information and ICTs must set these factors alongside the others that enterprises require. The research therefore investigated enterprise problems generally in order to understand the relative importance of information-related problems. Three general problem areas were identified as equally 'critical' by around $40 \%$ of enterprises:

- Access to skills. This was the main issue, being cited as 'very important' by an additional $52 \%$ of enterprises. Respondents most often identified poor existing management skills, lack of access to improved management skills, inability to acquire and retain skilled workers, and lack of access to skills training as their most significant constraints.

- Access to markets. Issues here were the need to increase sales to existing customers, and to expand/diversify the customer base.

- Access to finance. This was identified as a key problem by non-exporting manufacturers. Manufacturing exporters and service enterprises were much less concerned about finance, and much more concerned about skills and sales.

\section{Enterprise Information Gaps}

Overall, within formal sector SMMEs, the evidence suggests there is a large 'information needs gap' across a wide range of business activities. This gap was measured as the difference between stated demand for information from entrepreneurs and their success in obtaining a supply of such information.

Each of the problem areas identified above has an associated information component. It was therefore no surprise that information gaps accorded largely with prioritisation of those problems areas. For example, the largest gap for particular enterprise categories was as follows:

- For non-manufacturing exporters, the greatest need was for information that would lead to advice and/or assistance in accessing external financing and in solving internal financial problems. 
- For manufacturing exporters, the greatest need was for information concerning access to trained personnel and assistance with workforce training.

- For service enterprises, the greatest need was for information concerning management training opportunities and sources of new, skilled employees.

In addition, $72 \%$ of all enterprises had an urgent need to access information that would lead to increased sales by obtaining new local customers and/or by expanding into export markets.

However a distinction emerged between two root causes of the information gap. Information relating to management skills training, skilled employees, availability of land/premises, export markets and technical expertise was difficult to obtain primarily because those commodities/services are themselves in short supply locally. In contrast, difficulty in obtaining information relating to finance and new local customers (and, to a lesser extent, rules/regulations) related more to lack of access for SMMEs rather than lack of availability more generally. For example, in relation to finance, difficulties of accessing information were both the result of information barriers erected by lending institutions and the lack of capacities on behalf of business owners to effectively search out and access such information.

Of course, these are general observations, and it should be emphasised that enterprises are characterised by their diversity: depending upon the markets within which they operate; the goods and services they provide; and the capacities of business owners and employees. Each enterprise has its own individual problems and priorities, and hence 'enterprise-specific' information needs.

Nevertheless, the findings suggests at least one cross-cutting priority: the provision of better market/demand information. There have been a number of successful initiatives to improve provision of demand information for entrepreneurs in developing countries (Van Crowder, 1997; World Bank, 1998). These have used both ICT-based and nonelectronic methods to disseminate quantitative information such as market prices, and qualitative information such as details of distribution channels. Initiative sustainability is an issue, but sales growth has been an outcome in some cases.

\section{Conclusions}

The findings reported here are drawn from an initial fieldwork survey, based solely on formal sector SMMEs in Botswana, with partial response skews towards larger enterprises and IT-using enterprises. The conclusions presented must therefore be regarded as somewhat tentative.

In relation to investigation approaches, we reassert the point made at the beginning of the paper: in order to understand ICTs, you must first understand information. Taking information as the starting point requires the modelling and investigation of current enterprise information systems and information needs. This forms an essential basis for understanding the role that ICTs can and cannot play in the enterprise. Without such a 'bedrock', decisions about ICTs become merely reactive to the whims of current technology fads and fashions. 
Just as for technology, we must also take a systemic view of enterprises themselves, as shown in Figure 3:

Figure 3: A Systemic View of Enterprise

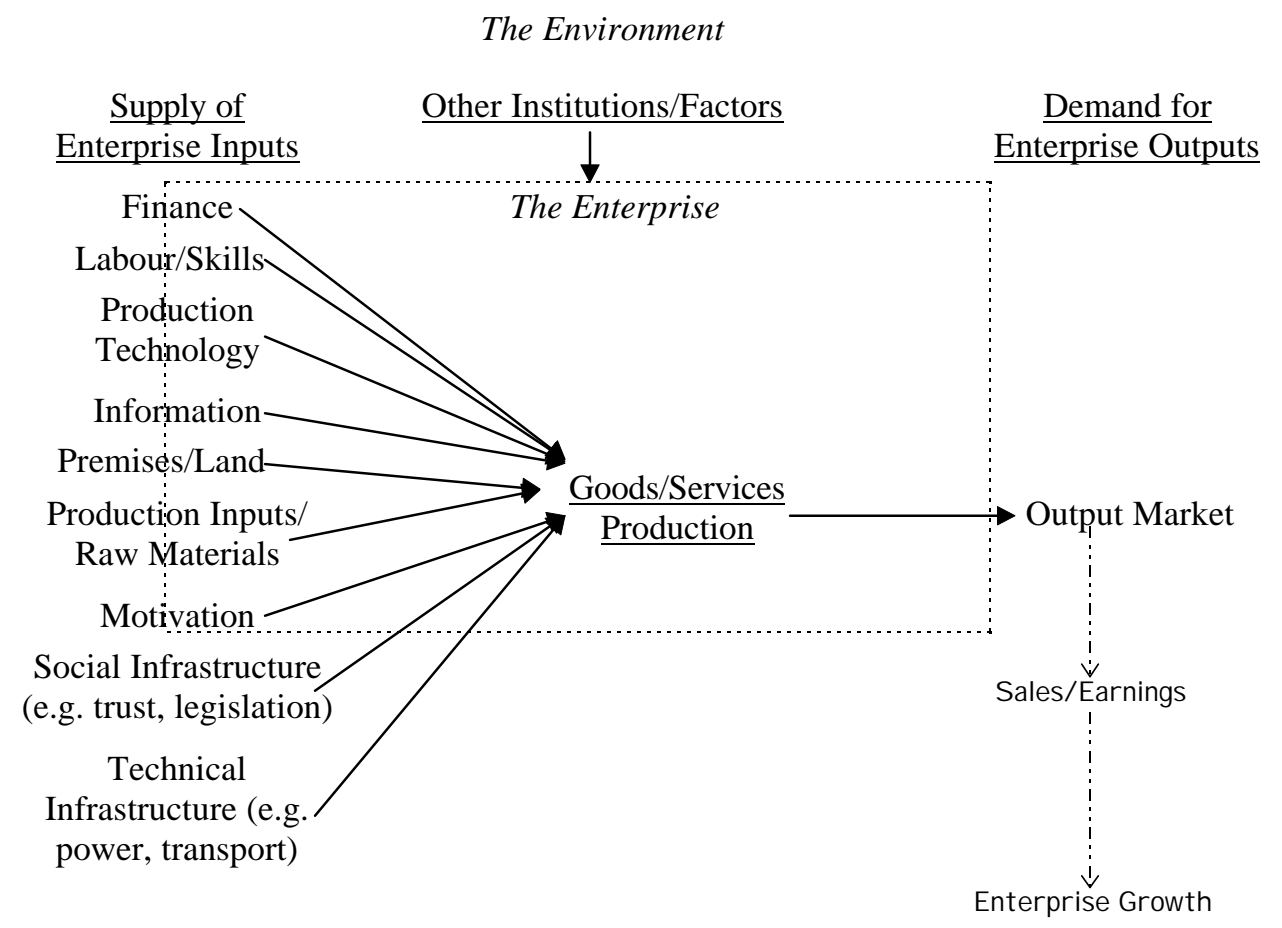

Such systemic views are a reminder, as were the questionnaire results, that information must be kept in perspective. Information gaps are certainly an issue for small entrepreneurs, but a more important part of the total small enterprise development picture are resources like skills, markets and money. Addressing information alone may be a necessary step in small enterprise development but it is far, far from being a sufficient one. And what is true for information must necessarily be true for the ICTs which provide more efficient or effective means of handling that information.

Entrepreneurs and support agencies must therefore take a multi-dimensional approach to enterprise development that encompasses a package of related resources. This is particularly true of information since the information component of all other resources is so intimately bound up with the resource itself.

Information-related interventions, by entrepreneurs or institutions, must also recognise the critical and continuing role to be played by informal information systems, and by 'non-electronic technologies' such as telephone, newsletter and the human body. The seductive nature of ICTs can easily pull interventions down a single, narrow track that deals just with ICT access and skills. Instead, a more holistic approach is required that provides information skills, communication skills, and assistance with improving organic-, literate- and intermediate-technology based systems as well as the more obvious ICT-focused areas.

Therefore, computing/Internet skills training should not be separated out but should form one component of task-focused training. The training programme should be, for 
instance, "Better Marketing", not "Using the Internet". Likewise, organisational change interventions should concentrate on improving particular organisational systems by whatever appropriate means rather than focusing just on the introduction of a new technology. The intervention aim should be, for instance, "to improve the enterprise's accounting systems", not "to introduce computers".

Such a task-/systems- not technology-driven approach is all the more vital given the environmental constraints which hold back ICT use. In Botswana, these include a lack of knowledge about ICTs, a lack of ICT implementation and use skills, a lack of finance, and a lack of connectivity. Such constraints suggest that informal/nonelectronic information system improvements may often be more feasible than those aimed at ICT-based systems.

Finally, the very diverse nature of the enterprises surveyed suggests the need for a differentiated development approach. One obvious differentiation would be between the needs of service, manufacturing export and non-exporting manufacturing enterprises. Certainly, those exporting and those not have a very different information systems profile and very different information needs.

Here, though, we will look at a slightly different categorisation, based on the sophistication of information systems in use in the organisation. Despite the caveats about techno-centrism, we will use technology-based categories because they are easy to identify and understand, and because they can be related relatively easily to different information practices and interventions. This categorisation therefore provides a way of targeting particular enterprises for particular information-related interventions.

\section{Recommendations for Enterprise Categories}

Five different enterprise categories emerged from the survey:

- Non-ICT users: enterprises that make no use of computers and have no immediate access to telecommunication services.

- Non-IT users: enterprises that make no use of computers, but have access to - and make regular use of - telecommunication services; primarily telephone and fax but with increasing use of mobile communications.

- Non-networked ICT users: enterprises with one or more computers on their premises, but with no network connections; they will have access to telecommunication services.

- Networked ICT users: enterprises with stand-alone computer(s) that lack internal networking, but which have an external email/Internet connection.

- Intensive ICT users: enterprises using two or more internally-networked computers that also have email/Internet connectivity. ${ }^{6}$

\footnotetext{
${ }^{6}$ For the purposes of discussion, the networked IT user and intensive IT user categories are combined below.
} 
Categorisation related to enterprise size, ownership and sector to some degree:

- More than $70 \%$ of non-ICT/non-IT users had less than five employees, whilst a similar percentage of medium enterprises (30-99 employees) fell into the networked/intensive ICT user categories.

- All but one of the non-ICT/non-IT user enterprises was owned by Botswana citizens, whilst two-thirds of the networked/intensive ICT user enterprises were owned by foreigners.

- More than half the non-exporting manufacturers were non-ICT/non-IT users, whilst $80 \%$ of manufacturing exporters and service enterprises were networked/intensive ICT users.

\section{Non-ICT Users}

Very few non-ICT users emerged from the initial round of fieldwork, but previous studies indicate that the majority of such enterprises are located in the non-formal sector (Daniels and Fisseha, 1992; Lisenda, 1997). Given the predominant role of the non-formal sector, this type of enterprise therefore constitutes the majority of enterprises within the SMME sector as a whole, and creates livelihoods for the largest number of people.

The potential for information- and ICT-related interventions is unclear, but we can surmise from other work (Heeks, 1999) that the information needs of such enterprises will be met more by informal, organic information systems than by formal, ICT-based information systems. Within the non-formal sector there is strong evidence that business owners place greater value on information received through personal contact, and are able to build up greater trust in personalised information channels and sources. Conversely, information received in a digitised form is generally non-personalised and distant, and lacks the trust components necessary when making decisions that may involve an element of risk. Environmental analysis suggests there are also likely to be substantial long-term financial, socio-cultural, and knowledge barriers that would need to be overcome before most business owners in this category could effectively utilise both ICTs and the information they handle.

There are two corollaries for ICT use. First, that where ICTs are used, they should provide a supplement, not substitute, for existing information systems. Second, that in most cases 'intelligent intermediaries' will be needed to bridge the financial, sociocultural, and knowledge gaps between what non-formal entrepreneurs have and what they would need in order to access and use ICT-borne information ${ }^{7}$.

Priorities for application of such intermediated access to ICTs probably lie in communication more than in processing of information. The formal information processing requirements of such enterprises are relatively limited, and can typically be met cost-effectively by improved paper-based methods. In communication of information, though, ICTs can substantially reduce costs and greatly increase access.

ICTs can provide infusions of external information that break the insularity and quality deficits of some informal social networks. They can be a means for communicating market/demand information (though this can equally, perhaps more appropriately, be delivered by non-ICT means). They can also disseminate information, most eye-

\footnotetext{
${ }^{7}$ For an assessment of different intermediary models, see Barton and Bear (1999).
} 
catchingly through Internet-mediated marketing of enterprise products and services. However, it must be recognised that the Internet is no panacea, and that many complementary inputs and actions are required if enterprises are to make use of the technology, even via intermediaries.

\section{Non-IT Users}

Lack of finance and lack of management/workforce skills were key perceived problems for this enterprise group, with over $90 \%$ of business owners in this category regarding them as critical or very important.

These enterprises have an obvious potential for expanding their use of IT systems. However, the lack of finance and skills will be a major constraint. Most could not afford to buy a personal computer and, if one was bought, most would find it difficult to obtain commensurate benefits in the short/medium term.

Current non-IT users are more likely to benefit from improvements in their existing information practices using the information systems and technology to which they already have access. There are a variety of ways in which business owners and employees can be assisted to improve their capacities for information access, processing and dissemination. These would include access to training for improving inter-personal communication skills, enhanced financial management skills to improve business efficiency, and training in sales and marketing techniques.

Within such enterprises, it is only when basic skills and/or financial stability have been significantly improved that any true benefit is likely to be gained from applying ICTs. Of course, like the non-ICT users, they would find value in intermediated access to ICTs. Again, communication is likely to be a priority: both receipt (for example of market prices) and dissemination (for example of product/service details).

\section{Non-Networked ICT Users}

Non-networked ICT users can be described as 'first-footers' in small business computing, and they are widespread throughout the manufacturing and service sectors covered in the survey. Although they have access to computers on the premises, levels of computer use are typically low. 39\% of 'users' actually made no use of their computers for everyday business activities. Amongst the remainder, by far the main use (71\% of actual users) was word processing. By contrast, only $20 \%$ of actual users had computerised basic business functions such as customer invoicing and internal accounting.

Non-networked ICT users frequently lack managerial capacities and they share many of the characteristics of non-IT users. The same preconditions for enhancing basic management and information skills would apply before investments in enhanced ICTs should be considered. Likewise, these enterprises will also benefit from improving their informal/non-electronic information systems. Nevertheless, there are greater ICT-related pressures within this group than those felt in the previous two categories:

- Such enterprises may have specific needs for ICTs, as in the printing and publishing sector, where competitive pressures driven by rapid technological change mean enterprises must 'adapt or die' in relation to ICTs. 
- Such enterprises may feel pressurised to expand their use of ICTs in order to achieve compatibility with customers or suppliers.

- Such enterprises may feel pressurised to adopt ICTs to keep up with competitors and to create an aura of modernity.

Such pressures were reflected in the $50 \%$ of respondents in this category who regarded upgrading their computer systems as critical to future business success.

However, evidence from interviews suggests significant problems amongst this category of 'first-footer' computer users. As reflected in the $39 \%$ figure above, it was not uncommon to find computers out of use or consigned to a back room, after initial failed attempts to adapt unfamiliar software to the needs of the business. This failure, in turn, arises from the gap that exists between the design conceptions of much business software and the organisational realities of many small enterprises (Heeks and Bhatnagar, 1999). Closing the design—reality gap will be a key priority, which will draw in issues of IT production strategy and software production skills within the country.

\section{Networked/Intensive ICT Users}

These enterprises - found mainly in the technical services, IT services and tourism sectors - make considerable, networked use of ICTs. Three quarters of them had computerised accounting and customer invoicing systems. Most other business functions, such as inventories, customer and supplier records, were computerised in about $60 \%$ of enterprises. Email and the Internet were used very or quite often by $85 \%$ of these enterprises, and computers were used for more complex business activities such as project planning by $50 \%$ of respondents.

All respondents regarded further upgrading and continued expansion of ICT-based systems as critical or very important to the future success of their businesses. However, interview evidence showed that such enterprises had applied and adapted such systems on a largely ad-hoc basis. In many cases, they lacked the employee skills to effectively manage the systems which had been developed. In other cases, the development process was deficient.

Overall, such enterprises will benefit from a more strategic approach to managing information, in order that the costs and benefits associated with improving both ICTbased and non-electronic systems can be evaluated. They also require complementary inputs to support their current systems, such as a better understanding of marketing and promotion as a precursor to making more effective use of the Internet. Lastly, better or best practice needs to be disseminated about the development and management of computerised information systems. 


\section{References}

Barton, C. (1997) Microenterprise Business Development Services, Microenterprise Best Practices, Bethesda, MD.

Barton, C. and Bear, M. (1999) Information and Communications Technologies: Are They the Key to Viable Business Development Services for Micro and Small Enterprises, Microenterprise Best Practices, Bethesda, MD.

BOCCIM (1994) Industry Survey. Botswana Confederation of Commerce, Industry and Manpower, Gaborone.

Briscoe, A.J. (1995) Assisting Small Businesses: Findings from a Study of Botswana's New Generation of Entrepreneurs, Working Paper No.2. Business School of Botswana, University of Botswana, Gaborone.

CSO (1997) Botswana Registry of Establishments. Central Statistical Office, Government of Botswana, Gaborone.

Daniels, L. and Fisseha, Y. (1992) Micro and Small-Scale Enterprises in Botswana: Results of a Nationwide Survey. Ministry of Finance and Development Planning, Gaborone.

Ferrand, D. and Havers, M. (1999) 'Information systems for microfinancial services', Small Enterprise Development, 10(1), p4-16.

Heeks, R.B. (1999) Information and Communication Technologies, Poverty and Development, Development Informatics Paper No.5. IDPM, University of Manchester, Manchester. http://www.man.ac.uk/idpm/idpm_dp.htm

Heeks, R. and Bhatnagar, S.C. (1999) 'Understanding success and failure in information age reform', in R.B. Heeks (ed.) Reinventing Government in the Information Age. Routledge, London.

ITU (1998) World Telecommunications Indicators. International Telecommunications Union, Geneva.

Kole, E. (1998) 'Supporting small enterprise with new technology', Appropriate Technology, 24(4), 21-23.

Lisenda, L. (1997) Small and Medium Enterprises in Botswana: Their

Characteristics, Sources of Finance, and Problems, Working Paper No.14. Botswana Institute for Development Policy Analysis, Gaborone.

Mansell, R. and Wehn, U. (eds) (1998) Knowledge Societies. Oxford University Press for UNCSTD, Oxford.

Ministry of Commerce and Industry (1999) Policy on Small, Medium and Micro Enterprises in Botswana, Government Paper No.1/1999. Ministry of Commerce and Industry, Government of Botswana, Gaborone. 
Presidential Task Group (1997) Vision 2016: Long-Term Vision for Botswana. Presidential Task Group, Government of Botswana, Gaborone.

Van Crowder, L. (1997) 'Marketing information systems for small-scale farmers', Information Development, 13(4), 179-83.

World Bank (1998) World Development Report. World Bank, Washington, DC. 